\title{
Responses of maize to different levels and sources of phosphorus application
}

\author{
Muhammad Asim ${ }^{1 *}$, Quaid Hussain ${ }^{2}$, Anwar Ali ${ }^{3}$, Saqib Farooq ${ }^{4}$, \\ Rayyan Khan ${ }^{1}$ and Syed Atizaz Ali Shah ${ }^{5}$ \\ 1. Department of Agronomy, Faculty of Crop Production Sciences, University of Agriculture, Peshawar-Pakistan \\ 2. Department of Plant breeding and genetics, Faculty of Crop Production Sciences, University of Agriculture, \\ Peshawar-Pakistan \\ 3. Department of Horticulture, Hazara University-Pakistan \\ 4. Department of Horticulture, Faculty of Crop Production Sciences, University of Agriculture, Peshawar-Pakistan \\ 5. Department of Soil Sciences, Faculty of Crop Production Sciences, University of Agriculture, Peshawar-Pakistan \\ *Corresponding author's email: asim.ktk91@ aup.edu.pk \\ Citation
}

Muhammad Asim, Quaid Hussain, Anwar Ali, Saqib Farooq, Rayyan Khan and Syed Atizaz Ali Shah. Responses of maize to different levels and sources of phosphorus application. Pure and Applied Biology. Vol. 6, Issue 3, pp10301036. http://dx.doi.org/10.19045/bspab.2017.600109

Received: 27/04/2017 Revised: 21/08/2017

Accepted: 28/08/2017

Online First: 30/08/2017

\section{Abstract}

Improper phosphorus management is a major factor contributing to low yield. An experiment comprising four levels $\left(90,120,150\right.$, and $180 \mathrm{~kg} \mathrm{ha}^{-1}$ ) and three sources of phosphorus (SSP, DAP, NP) was designed with the purpose to identified the best phosphorus level and source to gain higher yield of maize. The experiment was conducted at agriculture research farm Plato of The University of Agriculture Amir Muhammad Khan Campus Mardan during summer 2016 by using RCBD design replicated three times. The result indicated that phosphorus sources and control vs. rest influenced significantly $(\mathrm{P}<0.05)$ on plant height $(200.2 \mathrm{~cm})$, biological yield $\left(12556.3 \mathrm{kgha}^{-1}\right)$, grain yield $\left(3481 \mathrm{kgha}^{-1}\right)$, thousand grain weight $(231.7 \mathrm{~g})$, harvest index $(32.2$ $\%)$ while had no significant effects on grain rows ear $^{-1}(14.3)$. DAP (46\% P) source increase number of ear plant ${ }^{-1}(1.5)$, plant height $\left(5.4 \mathrm{~m}^{-2}\right)$, biological yield $\left(12556.3 \mathrm{kgha}^{-1}\right)$, grain yield $\left(3481 \mathrm{kgha}^{-1}\right)$, thousand grain weight $(231.7 \mathrm{~g})$ and harvest index $(32.2 \%)$. It is concluded that the application DAP source produces maximum yield of maize crop.

Keywords: Zea mays L., Phosphorus, plant height, 1000 grain weight, grain yield.

\section{Introduction}

Maize (zea mays L.) ranked $2^{\text {nd }}$ on global scale after wheat in total production and categories third among the cereals. It was extensively grown on temperate, tropical and region of the world. Maize is an important crop because of its food and fodder value. Maize is one of the valuable crops in Khyber Pakhtunkhwa (KPK) province. It is used in many things as ingredient like bread making, corn, flakes, corn starch, corn syrup, paper making, and textile and food industries. The kernel contains $77 \%$ starch $2 \%$ sugar $9 \%$ protein and highly saturated fatty acid. On the total crop area and value of agriculture output about $4.8 \%$ and $3.5 \%$ accounts for maize respectively. Due to exhaustive property of maize it absorbs large quantity of nutrient from the soil as compare to other cereals. Phosphorus is one of the vital nutrients for high yield among the essential nutrients for 
high yield [1] and mainly controls plant growth parameters [2].Usually phosphorus is the succeeding essential and yield restraining nutrient after nitrogen. Phosphorus affects significantly plant growth including grain yield; whereas similar effect of phosphorus submission on physiological characters such as leaf area, plant height, leaves per plant, and on dry matter yield It is readily translocate within the plants, during the vegetative growth of the plant like formation of cells, roots developing, stem and leaves etc it move from older to younger tissues. Phosphorus applications stimulate blooming, seed formation and increased yield [3].The $\mathrm{P}$ deficiency is most common in the soil of Pakistan [4].

Lake of phosphorus affects plant growth especially leaf growth, earlier and to a greater extent than photosynthesis per unit area [5]. Many sources of $P$ fertilizers are available on the market, and the three most popular fertilizers used by farmers are single superphosphate (SSP), NP, and DAP. Differences among these fertilizers include their solubility and nutrient concentrations. Increased fertilizer costs, new $\mathrm{P}$ enhancer products in market, and challenges of corn production prompted this investigation of ways to enhance the effectiveness of $\mathrm{P}$ fertilizer and to decide the best source and suitable level of $\mathrm{P}$ fertilizers for high maize yield. Therefore, it was imperative to study the effects of phosphorus on maize yield and its components.

Keeping in view the important effect of phosphorus application, the present study was undertaken to evaluate the usefulness of $\mathrm{P}$ on yield.

\section{Materials and methods}

To study the effect of level and sources of phosphorus on yield of maize an experiment was conducted at Agricultural Research farm Palato, Amir Muhammad Khan Campus Mardan during the kharif season 2013. The experiment was lay out randomized complete block design (RCBD), with $3.75 \mathrm{~m} \mathrm{x} 3$ having row to row (R-R) distance of $0.75 \mathrm{~m}$ and plant to plant (P-P) distance of $0.25 \mathrm{~m}$ and the field was ploughed with one moldboard plough and rotarvator. Both Phosphorus levels and sources were studied. Maize variety Azam was sown and apply $\mathrm{N}$ at basel dose at crop knee height stage knee at the rate of $120 \mathrm{~kg} / \mathrm{ha}$. Phosphorus sources SSP, DAP, and NP was incorporate before sowing with desire levels of phosphorus.

\section{Statistical analysis}

The recorded information were subjected to examination of difference strategy for the data recorded on each parameter was subjected to analysis of variance (ANOVA) practice appropriate for a RCBD through MSTATC PC program. By applying (LSD) test at $5 \%$ probability value as proposed by Steel and Torrie [6].

\section{Results and discussion Plant height (cm)}

Data regarding plant height given in the Table 1 indicated that in control vs. rest phosphorus had significant effect on plant height $(\mathrm{cm})$ whereas non-significant influenced were showed by phosphorus level, sources and on their interaction. Long stature plants $(200.2 \mathrm{~cm})$ were recorded by in control plots whereas short stature (170 $\mathrm{cm}$ ) of plants was found in rest plots. Phosphorus enhances the root development which greatly affects the general plant development execution; in this way the $\mathrm{P}$ in rest plots brought about the higher stature plants. Advancement impact of high P level on plant tallness was presumably due to increment in $\mathrm{P}$ application. Plant stature of maize expanded with increment in $P$ application by Arain et al. [7]. 
Table 1. Plant height $(\mathrm{cm})$ of maize as affected by level and sources of phosphorus

\begin{tabular}{|c|c|c|c|c|c|}
\hline \multirow[t]{2}{*}{$\mathrm{P}_{2} \mathrm{O}_{5}$ Sources } & \multicolumn{4}{|c|}{ Phosphorous Levels (Kg ha $\left.{ }^{-1}\right)$} & \multirow[t]{2}{*}{ Mean } \\
\hline & 90 & 120 & 150 & 180 & \\
\hline SSP & 191.01 & 178.82 & 178.82 & 199.14 & $189.99 b$ \\
\hline DAP & 203.2 & 215.39 & 215.39 & 205.23 & $207.26 a$ \\
\hline NP & 205.23 & 195.07 & 195.07 & 207.26 & $203.20 \mathrm{ab}$ \\
\hline Mean & 200.49 & 199.81 & 196.43 & 203.88 & \\
\hline \multirow[t]{3}{*}{ Control vs Rest } & Control & & $170.7 \mathrm{~b}$ & & \\
\hline & Rest & & $200.2 \mathrm{a}$ & & \\
\hline & Significant & & $* *$ & & \\
\hline \multicolumn{3}{|c|}{ LSD 0.05 for Sources } & 6.86 & & \\
\hline
\end{tabular}

\section{Biological yield $\left(\mathrm{kg} \mathrm{ha}^{-\mathbf{1}}\right)$}

Data pertaining biological maize yield shown in the Table 2 revealed that maize biological yield significantly affected by phosphorus sources, Table 2 also showed significant effect in control versus (vs.) rest. While the interaction between P-level and sources was found non-significant. Highest biological yield $\left(12556.3 \mathrm{~kg} \mathrm{ha}^{-1}\right)$ was gained in the plots applied with DAP sources followed by NP $\left(10454.7 \mathrm{~kg} \mathrm{ha}^{-}\right.$ $\left.{ }^{1}\right)$,compare to lower biological yield (9178.7 $\mathrm{kg} \mathrm{ha}{ }^{-1}$ ) was recorded by SSP, similarly
(10729.9 $\mathrm{kg} \mathrm{ha}^{-1}$ ) was recorded by rest compare to control $\left(6450 \mathrm{~kg} \mathrm{ha}^{-1}\right)$. As the Pconcentration in soil has close association to root growth of maize plants was best DAP source which additionally brought about best natural yield because of proficient photosynthesis and other physiological capacities at this $\mathrm{P}$ level. That is the reason the organic yield was the most minimal in the control vs. rest. The finding are also coincide to the finding of [8], which also got lower biological yield at greater soil $\mathrm{pH}$ which makes $\mathrm{P}$ unavailable to the crop.

Table 2. Biological yield maize as affected by level and sources of phosphorus

\begin{tabular}{|c|c|c|c|c|c|}
\hline \multirow[t]{2}{*}{$\mathrm{P}_{2} \mathrm{O}_{5}$ Sources } & \multicolumn{4}{|c|}{ Phosphorous Levels $\left(\mathrm{Kg} \mathrm{ha}^{-1}\right)$} & \multirow[t]{2}{*}{ Mean } \\
\hline & 90 & 120 & 150 & 180 & \\
\hline SSP & 7912.5 & 9775 & 8877.2 & 10150 & $9178.7 \mathrm{c}$ \\
\hline DAP & 13825 & 10000 & 12912.5 & 13487.5 & $12556.3 \mathrm{a}$ \\
\hline $\mathbf{N P}$ & 9575 & 11612.5 & 10093.8 & 10537.5 & $10454.7 \mathrm{~b}$ \\
\hline Mean & 10437.5 & 10462.5 & 10627.8 & 11391.7 & \\
\hline \multirow[t]{3}{*}{ Control vs Rest } & Control & & $6450 \mathrm{~b}$ & & \\
\hline & Rest & & $10729.9 \mathrm{a}$ & & \\
\hline & Significant & & $* *$ & & \\
\hline \multicolumn{3}{|l|}{ LSD 0.05 for Sources } & 472.3 & & \\
\hline
\end{tabular}

\section{Number of grain rows ear-1}

Statistical analysis of the data shown in the Table 3 indicated that control vs. rest was found non-significant, followed by P- level, sources and their interaction. Maximum of (14.3) rows ear ${ }^{-1}$ was recorded from rest as compare to control with the minimum of
(13.0) rows ear ${ }^{-1}$. Presumably at the season of number of grain columns per ear development there was no opposition between physiological sink for-up of assets. The quantity of grain lines per ear controlled generally genetically, and uninfluenced by sources of info and ecological conditions; as 
it were, in various natural conditions, the quantity of grain columns $\mathrm{ear}^{-1}$ had a practically steady rate in comparative figures [9].

Table 3. Grains rows ear ${ }^{-1}$ maize as affected by levels and sources of phosphorus

\begin{tabular}{|l|l|l|l|l|l|}
\hline \multirow{2}{*}{ P $_{2} \mathrm{O}_{5}$ Sources } & \multicolumn{4}{l|}{ Phosphorous Levels $\left(\mathbf{K g ~ h a}^{-\mathbf{1}}\right)$} & \multirow{2}{*}{ Mean } \\
\cline { 2 - 6 } & $\mathbf{9 0}$ & $\mathbf{1 2 0}$ & $\mathbf{1 5 0}$ & $\mathbf{1 8 0}$ & \\
\hline SSP & 13.6 & 14.9 & 14.4 & 15.3 & 14.6 \\
\hline DAP & 14.4 & 13.9 & 13.8 & 14.4 & 14.1 \\
\hline NP & 14.2 & 14.3 & 13.7 & 14.2 & 14.1 \\
\hline Mean & 14.1 & 14.4 & 14 & 14.7 & \\
\hline Control vs Rest & Control & & 14.3 & & \\
\hline & Rest & & 13 & & \\
\hline & Significant & & $\mathrm{ns}$ & & \\
\hline
\end{tabular}

\section{Number of grain ear ${ }^{-1}$}

Data presented in the Table 4 statistical analysis showed that control vs. rest significantly affected by P-level and sources, while interaction found non-significant. The highest of (44.31) grain ear $^{-1}$ while minimum of (345.3) as compare to control. Phosphorus affect the overall plant performance as it have direct effect on the plant root growth, the administrations of $\mathrm{P}$ at the rate of $0 \mathrm{~kg}$ ha- 1 that in control brought about minimal number of grains ear- 1 . The outcomes are as per those of [10] who reported that phosphorous fertilizer applications significantly affected the grains $\mathrm{ear}^{-1}$, and also reported that number of grains cob-1 of maize increased with increase in $\mathrm{P}$ application.

Table 4. Number of grains ear ${ }^{-1}$ maize as affected by level and sources of phosphorus

\begin{tabular}{|l|l|l|l|l|l|}
\hline \multirow{2}{*}{$\mathbf{P}_{2} \mathrm{O}_{5}$ Sources } & \multicolumn{4}{l|}{ Phosphorous Levels $\left(\mathrm{Kg} \mathrm{ha}^{-\mathbf{1}}\right)$} & \multirow{2}{*}{ Mean } \\
\cline { 2 - 6 } & $\mathbf{9 0}$ & $\mathbf{1 2 0}$ & $\mathbf{1 5 0}$ & $\mathbf{1 8 0}$ & \\
\hline SSP & 426 & 456.4 & 428.4 & 445.3 & 439.1 \\
\hline DAP & 486.9 & 433.2 & 480.4 & 487.3 & 472 \\
\hline NP & 448.2 & 348.4 & 440.4 & 414.7 & 412.9 \\
\hline Mean & 453.7 & 412.7 & 449.8 & 449.1 & \\
\hline Control vs Rest & Control & & $345.3 \mathrm{~b}$ & & \\
\hline & Rest & & $441.3 \mathrm{a}$ & & \\
\hline
\end{tabular}

\section{Grain yield $\left(\mathrm{kg} \mathrm{ha}^{-1}\right)$}

Grain yield data shown in Table 5 . Statistical analysis showed that phosphorus levels and sources significantly influenced on grain yield of maize. The interaction was also found significant. Control vs. rest found significant. The source DAP revealed greater grain yield $\left(3481 \mathrm{~kg} \mathrm{ha}^{-1}\right)$,followed by NP $\left(3360 \mathrm{~kg} \mathrm{ha}^{-1}\right)$ whereas lower grain yield $\left(2831 \mathrm{~kg} \mathrm{ha}^{-1}\right)$ was observed from SSP, similarly higher grain yield of $\left(3324 \mathrm{~kg} \mathrm{ha}^{-1}\right)$ was recorded in rest plots as compare to control $\left(2184 \mathrm{~kg} \mathrm{ha}^{-1}\right)$. The expansion in grain yield because of NP application was additionally revealed by Khan et al. [11], the grain yield of maize expanded with increment in $\mathrm{P}$ application [10]. That is the reason the grain yield was the most minimal in the control plots since absence of $\mathrm{P}$ decayed the roots development of the plants which adversely influenced the other physiological elements of the maize plants in the control plots. 
Table 5. Grain yield $\left(\mathrm{kg} \mathrm{ha}^{-1}\right)$ of maize as affected by level and sources of phosphorus

\begin{tabular}{|c|c|c|c|c|c|}
\hline \multirow[t]{2}{*}{$\mathrm{P}_{2} \mathrm{O}_{5}$ Sources } & \multicolumn{4}{|c|}{ Phosphorous Levels $\left(\mathrm{Kg} \mathrm{ha}^{-1}\right)$} & \multirow[t]{2}{*}{ Mean } \\
\hline & 90 & 120 & 150 & 180 & \\
\hline SSP & 2447 & 2727 & 2953 & 3198 & $2831 \mathrm{~b}$ \\
\hline DAP & 3213 & 2967 & 3517 & 3589 & $3321 \mathrm{a}$ \\
\hline $\mathbf{N P}$ & 3372 & 3529 & 2987 & 3553 & $3360 \mathrm{a}$ \\
\hline Mean & 3011 & 3074 & 3152 & 3447 & \\
\hline \multirow[t]{3}{*}{ Control vs Rest } & Control & & $1456.3 b$ & & \\
\hline & Rest & & $2422.3 \mathrm{a}$ & & \\
\hline & Significant & & $* *$ & & \\
\hline \multicolumn{3}{|c|}{ LSD 0.05 for Sources } & 137.9 & & \\
\hline
\end{tabular}

\section{Thousand grain weight (g)}

Statistical analysis of the data on 1000 grain weight shown in Table 6 indicated that phosphorus sources significantly influenced on thousand grain weight $(\mathrm{g})$. P-level and their interaction with sources was found non-significant. Control vs. rest found significant. Greater thousand grain weight
(231.7 g) was reported from DAP ,followed by NP (200.8 g) whereas lower thousand grain weight (195 g) was recorded in SSP treatment, similarly higher thousand grain weight of (209.4 g) was recorded in rest plots as compare to control recorded (136.7 g).

Table 6. 1000 grain weight (g) of maize as affected by levels and sources of phosphorus

\begin{tabular}{|l|l|l|l|l|l|}
\hline \multirow{2}{*}{ P2O5 Sources } & \multicolumn{4}{l}{ Phosphorous Levels (Kg ha-1) } & \multirow{2}{*}{ Mean } \\
\cline { 2 - 5 } & $\mathbf{9 0}$ & $\mathbf{1 2 0}$ & $\mathbf{1 5 0}$ & $\mathbf{1 8 0}$ & \\
\hline SSP & 183.3 & 193.3 & 196.7 & 210 & $195.8 \mathrm{~b}$ \\
\hline DAP & 223.3 & 216.7 & 220 & 266.7 & $231.7 \mathrm{a}$ \\
\hline NP & 216.7 & 196.7 & 176.7 & 213.3 & $200.8 \mathrm{a}$ \\
\hline Mean & 3011 & 3074 & 3152 & 3447 & \\
\hline & Control vs Rest & & $136.7 \mathrm{~b}$ & & \\
\hline & Rest & & $209.4 \mathrm{a}$ & & \\
\hline LSD 0.05 for Sources & Significant & & $* *$ & & \\
\hline
\end{tabular}

\section{Harvest index (\%)}

Data on pertaining harvest index presented in Table 7. Its statistical analysis showed that harvest index significantly influenced by phosphorus sources. While P-level and their interaction $(\mathrm{P} \times \mathrm{S})$ had non-significant effect on harvest index. Control vs. rest was also found non-significant. Maximum harvest index of $(32.2 \%)$ was recorded from NP source and minimum $(26.5 \%)$ by DAP application. Similarly the mean value of control plots showed greater harvest index of $(33 \%)$ and lower of $(30.4 \%)$ from the rest. Results were in agreement with finding most of the workers like [11]. 
Table 7. Harvest index of maize as affected by level and sources of phosphorus

\begin{tabular}{|l|l|l|l|l|l|}
\hline \multirow{2}{*}{$\mathbf{P}_{2} \mathrm{O}_{5}$ Sources } & \multicolumn{4}{l|}{ Phosphorous Levels $\left(\mathbf{K g ~ h a}^{-1}\right)$} & \multirow{2}{*}{ Mean } \\
\cline { 2 - 5 } & $\mathbf{9 0}$ & $\mathbf{1 2 0}$ & $\mathbf{1 5 0}$ & $\mathbf{1 8 0}$ & \\
\hline SSP & 31 & 32.7 & 35.5 & 31.5 & $32.2 \mathrm{a}$ \\
\hline DAP & 25 & 29.6 & 24.6 & 26.7 & $26.5 \mathrm{~b}$ \\
\hline NP & 35.2 & 30.4 & 29.6 & 33.7 & $32.7 \mathrm{a}$ \\
\hline Mean & 30.4 & 30.9 & 29.9 & 30.6 & \\
\hline Control vs Rest & Control & & $33.8 \mathrm{a}$ & & \\
\hline & Rest & & $30.4 \mathrm{~b}$ & & \\
\hline & Significant & & $*$ & & \\
\hline LSD 0.05 for Sources & & & 0.9 & & \\
\hline
\end{tabular}

\section{Conclusion and recommendation}

It was conclude that phosphorous application in the form of DAP or NP enhanced grain yield of maize. The use of $\mathrm{P}$ at the rate $120 \mathrm{~kg} \mathrm{ha}^{-1}$ in the form of NP or P at the rate $180 \mathrm{~kg} \mathrm{ha}^{-1}$ in the form of DAP enhanced grain yield of maize and hence recommended for higher yield of maize in agro-ecological condition of Mardan.

\section{Authors' contributions}

Conceived and designed the experiments: $\mathrm{M}$ Asim, Performed the Experiments: M Asim \& S Farooq, Analyzed the Data: R Khan \& SAA Shah, Contributed reagents/ materials/ analysis tools: A Ali \& Q Hussain, Wrote the paper: M Asim.

\section{Refrences}

1. Chen ML, Jiang XL, Zoov BY \& Zheri ZY (1994). Mathematical models and best combination of high yield cultivation technique for rapeseed variety Zhenyouyoum. Acta Agric Zhejiiangenesis 6: 22-26.

2. Wojnowska T, Panak H \& Seikiewiez $S$ (1995). Reaction of winter oilseed rape to increasing levels of nitrogen fertilizer application under condition of Ketizyn Chernozem. Rosling Oleiste 16: 173-180.

3. Ayub M, Nadeem MA, Sharar MS \& Mahmood N (2002). Response of maize (Zea mays L.) fodder to different levels of nitrogen and phosphorus. Asian J Pl Sci 1: $352-354.3$
4. Rasheed M, Khalid J \& Hussain M (2004). Biological response of maize to variable grades of phosphorus and planting geometry. Int J Agri Biol 6(3): 462-464.

5. Plénet DA, Mollier \& Pellerin S (2000). Growth analysis of maize field crops under phosphorus deficiency. II. Radiation-use efficiency, biomass accumulation and yield components. Plant and Soil J 224(2): 259-272.

6. Steel RGD \& Torrie JH (1980). Principles and procedures of statistics, a biological approach, 2nd ed. Mc Graw Hill, Inc. New York, Toronto, London.

7. Arain AS, Aslam SM \& Tunio AKG (1989). Performance of maize hybrids under varying NP fertilizer environments. Sarhad J Agric 5(6): 623-626.

8. Singaram P \& Kothandaraman GV (1994). Studied on residual, direct and cumulative effect of phosphorus sources on the availability, content and uptake of phosphorus and yield of maize. Madras Agric J 81 (8): 425- 429.

9. Ghaderi J \& Majidian M (2003). Effect of nitrogen and irrigation levels during milky and dough stages of grain on yield, yield components and water use efficiency in corn. Journal of Science and Technology of Agriculture and Natural Resources 2: 103-112. 
10. Arain AS, Aslam SM \& Tunio AKG (1989). Performance of maize hybrids under varying NP fertilizer environments. Sarhad J Agric 5(6): 623626.
11. Khan MA, Abid M, Labar HN \& Masood MU (2005). Effect of phosphorous levels on growth and yield of maize (zea mays L.) cultivars under saline Conditions. Int J Agric and Bio 7(3): 511-514. 